\title{
Helping Pre-Service Student Teachers Develop Teaching Skills in English Proficiency Courses in an EFL Teacher Education Program: A Phenomenological Study
}

\author{
Angel María Dávila \\ Department of EFL Teacher Education, Universidad Nacional de Educación (UNAE), Ecuador
}

Received March 10, 2020; Revised March 26, 2020; Accepted April 19, 2020

Copyright $\mathrm{C} 2020$ by authors, all rights reserved. Authors agree that this article remains permanently open access under the terms of the Creative Commons Attribution License 4.0 International License

\begin{abstract}
Teacher education programs seek to equip EFL pre-service student teachers with pedagogical and teaching skills. Existing research showed that pre-service teacher preparation programs deliver pedagogical knowledge and teaching skills in the form of courses focusing on pedagogy and teaching, demonstrative classes, and teaching practicums. However, sometimes this is not enough to prepare EFL teachers well. This fact has made some teacher preparation programs to explore other alternatives. Therefore, the purpose of this qualitative phenomenological study was to examine the lived experiences of 10 EFL teacher educators and 10 pre-service EFL student teachers about the development of English teaching skills in courses meant to develop English proficiency in a pre-service EFL teacher education program at a public university in Nicaragua. Data were collected utilizing structured interviews, document analysis, and classroom observations. Findings demonstrated that English proficiency courses are an excellent source to help pre-service student teachers develop pedagogical and didactic knowledge. To achieve that, EFL teacher educators provide student teachers with a didactic explanation of teaching strategies they use to teach English skills. Student teachers, on the other hand, keep a record of those explanations in a diary with their reflections about the effectiveness of teaching and learning strategies. Student teachers are given opportunities to teach their classmates demo classes using some of the strategies or activities their professors used. Student teachers found this way of acquiring teaching skills challenging but useful. In the beginning, they feel nervous; however, as they progress, they get used to that integrated learning approach. Finally, participants said that the pedagogical diaries created by student teachers are used not only in demo lessons but also in their teaching practicum as well as when student teachers teach for the first time in schools.
\end{abstract}

Keywords English Teaching Skills, Pre-Service Student Teachers, English Proficiency

\section{Introduction}

In the last three decades, English as a Foreign Language (EFL) teacher education programs have augmented in universities worldwide. It is because English has become one of the most studied languages in the world [1,2]. Nowadays, English is the means of communication in a plethora of scenarios such as science, information technology, business, entertainment, tourism, education, and diplomacy [1]. This fact has motivated universities to offer more and more EFL teacher education programs. With such degrees, universities seek to prepare qualified English teachers with the knowledge and skills that would allow them to be effective teachers in the EFL classroom.

The increase of EFL teacher education programs has also motivated researchers and educators to investigate the quality of those programs. Part of the existing research has centered on examining language teachers' knowledge base. Research has demonstrated that language teachers need to develop a set of knowledge to be effective teachers. For example, they need to acquire native or native-like language proficiency, content knowledge, pedagogical knowledge, pedagogical content knowledge, knowledge of learning theories, knowledge of the target language and related disciplines, knowledge of learners, assessment knowledge, knowledge of technology, research knowledge, curriculum knowledge, contextual knowledge, and academic literacy [3-10]. Richards [11] said that at macro and micro-curriculum levels, the knowledge base is delivered to pre-service student teachers in three ways. First, there are language teacher education programs that 
follow a scholar academic approach to organize and deliver their curricula [12-14]. Richards [11] called this curriculum form the Forward Curriculum Design. It means that language curriculum developers follow a linear logic to plan the curriculum. This logic sequence places the target content first. In the second place, it considers teaching methodologies and strategies. Lastly, the outcomes are addressed. The second form of delivering knowledge base to pre-service language teachers is using a more learner-centered curriculum approach [12-14], which Richards [11] named as Central Curriculum Design. In this case, teaching methodologies and strategies receive more value than content and outcomes. Lastly, there are other language teacher education programs that organize and deliver their curricula using a product-focused curriculum approach called Backward Curriculum Design [11-16]. This curriculum model entails a thoughtful process to determine the expected learning outcomes first. Then, assessment evidence is chosen carefully. Finally, content and teaching methodologies are selected, but only those that will contribute to achieving the expected outcomes $[11,13,15]$.

Teaching skills are among the essential skills out of the knowledge and skills that pre-service teachers need to acquire and develop in teacher education programs. Teaching skills have received different names. For example, Shulman [17] referred to it as pedagogical content knowledge (PCK). According to Shulman [17], PCK is the competence that teachers develop with teaching experience to transform and adapt content to make it accessible to learners. Even though Shulman [17] is not a language educator, he has influenced educators and researchers in the field of language teacher education regarding the knowledge base that teachers must possess. Thus, in language teacher education, teaching skills have been referred as pedagogic content knowledge [5]; knowledge of learners, time, and learning management [9]; pedagogical reasoning and decision making and teaching skills [10], teaching skills (Macías, 2013), and didactic knowledge and teaching skills [4]. Further, EFL teaching experience comprises the interplay of knowledge and skills such as knowledge of learners, content knowledge, pedagogical knowledge, English proficiency, communication skills, assessment knowledge, curricular knowledge, material development knowledge, knowledge of L2 related disciplines, contextual knowledge, and teaching skills $[3,4,5,9,10,18$,$] , and in EFL contexts it also$ includes experience as a language learner $[3,4,6,8,19,20]$.

However, sometimes student teachers do not encounter sufficient real teaching opportunities in pre-service teacher education programs. In some cases, what is at the disposal of student teachers is a short teaching practicum at the end of their undergraduate degrees in which they are expected to apply what they learned. In other cases, EFL teacher education programs may include practicums every semester; however, the emphasis might not be on teaching but on learning about education and school systems. In either case, student teachers end up receiving mostly procedural knowledge, knowing about teaching [21], and not enough practical knowledge, knowing how to teach [21]. Based on research and practice, both types of knowledge are essential [3,4,6,8,9,10]. Accordingly, student teachers should be provided with opportunities to apply theoretical knowledge as well as to theorize teaching practices.

Therefore, considering the premise that pre-service EFL teacher education programs seek to offer quality education, but practice indicates that teaching opportunities are sometimes relegated to short practicums, how can language teacher education programs provide other teaching opportunities to pre-service English teachers to develop teaching skills? This study tried to inform this question by learning about the lived experiences that EFL teacher educators and pre-service student teachers had about developing teaching skills in courses that were not necessarily meant to deliver pedagogical and didactic knowledge in a pre-service EFL teacher education program at a public university in Nicaragua. As researchers and EFL teacher educators, we thought that that was an interesting research phenomenon to investigate and share with other researchers and educators in the field of EFL teacher education. To pursue this study, we proposed the following research purpose and questions.

\subsection{Purpose of the Study}

The purpose of this qualitative phenomenological study was to examine the lived experiences of $10 \mathrm{EFL}$ teacher educators and 10 pre-service EFL student teachers about the development of English teaching skills in courses devoted to developing English proficiency in a pre-service EFL teacher education program at a public university in Nicaragua.

\subsection{Central Research Question}

How do EFL teacher educators and pre-service student teachers develop English teaching skills in courses devoted to developing English proficiency in a pre-service EFL teacher education program at a public university in Nicaragua?

\subsubsection{Sub-research Questions}

- What is the theoretical rationale that motivated EFL teacher educators to teach English teaching skills in courses devoted to developing English proficiency in a pre-service EFL teacher education program?

- What strategies do EFL teacher educators and pre-service student teachers use to develop English teaching skills in courses devoted to delivering 
English proficiency in a pre-service EFL teacher education program?

- What benefits do pre-service EFL student teachers obtain from taking English proficiency courses in which EFL teacher educators provide overt pedagogical elucidations of teaching strategies and teaching activities?

\section{Research Methodology}

In this section, we elucidate the research paradigm and methodology used to conduct this study. To begin with, we carried out this study under a post-positivist qualitative research paradigm [22]. The research methodology we applied to inform the whole study was a constructivist interpretative methodology [22] because we made the best effort to analyze the data inductively. In the next sections, we explicate how the study was conducted.

\subsection{Research Design}

We used phenomenology to conduct this inquiry. We applied phenomenology because this research approach seeks to understand and describe people's lived experiences about a phenomenon [23-24]. Specifically, we chose transcendental phenomenology. Transcendental phenomenology is conducted under four premises; namely, a description of informants' lived experiences about a phenomenon; lived experiences are told as accurately as possible, and researchers' judgments about the phenomenon are suspended, giving more value to participants' voices; meaning is ascribed to lived experiences, and reality is only in the experiences of the participants [26]. We think that this research approach fitted our study because we sought to examine the lived experiences of EFL teacher educators and pre-service EFL student teachers about the development of English teaching skills in courses devoted to developing English proficiency.

\subsection{Research Site}

According to Hycner [27] and Creswell [28], the phenomenon under investigation and researchers' judgments help investigators select both research sites and potential participants to collect meaningful data to inform research questions. Therefore, we selected the research site purposefully. The research site was a pre-service EFL teacher education program at a public university in Nicaragua. We chose explicitly that pre-service EFL teacher education program because both teacher educators and student teachers had experienced the target research phenomenon, namely, the development of teaching skills in courses devoted to acquiring English proficiency.

\subsection{Participants}

To recruit potential participants, we used purposive sampling. Purposive sampling is considered an appropriate form of non-probability sampling $[29,30]$. The population of this study consisted of 20 teacher educators and 400 student teachers. From this population, 10 teacher educators and 10 student teachers were recruited purposefully using consent forms. The selection criteria for teacher educators were 1) be teaching courses to develop English proficiency, 2) had at least three years of teaching experience in the target pre-service EFL teacher education program, 3) be willing to participate in the study, and 4) be willing to be observed while teaching. As for student teachers, they had: 1) be taking English proficiency courses, 2) had taken at least two English courses before in the target EFL teacher education program, 3) be willing to participate in the study, and be willing to be observed while taking English classes.

\subsection{Data Collection}

To gather data, we used three techniques. First, we conducted one-shot structured interviews. Both teacher educators and student teachers were interviewed for 60 minutes. We conducted the interviews to examine participants' lived experiences about developing teaching skills in courses designed to acquire English proficiency. To move from one participant to another, we used what we called the spiral interviewing approach. That is, after we interviewed participant one, we transcribed that interview and carried out a pre-data analysis. That pre-data analysis helped us ameliorate the types of questions in the original interview protocol as well as add or delete some of the questions before interviewing the next informant. We proceeded that way to collect more meaningful data to inform our study better. Second, we observed the target participants while teaching English courses. We observed five different English courses, namely, Integrated English skills I: Listening and speaking, Integrated English skills II: Listening and speaking, Integrated English skills I: reading and writing, Integrated English skills II: reading and writing, and English pronunciation I and II. We observed each course twice. The purpose of the observations was to collect more data about the target phenomenon and verify part of the interview data collected. Lastly, we used document analysis for data gathering. We analyzed lesson plans used by the EFL teacher educators to teach some lessons in the target courses we observed. Also, we asked student teachers to let us scope out some of their diaries used to record teaching strategies and activities utilized by their professors when teaching English skills, which they also used to give demo classes as part of their English classes. In short, we used those data collection data strategies because, according to Lichtman [31], interviews, observation, and document analysis are data gathering techniques widely used in qualitative research. 


\subsection{Data Analysis}

We used the Interactive Model of Qualitative Data Analysis to analyze the data gathered [32]. This model has four stages, namely, data collection, data display, data condensation, and conclusions drawing and verification [32]. Data collection was performed in three steps. We interviewed EFL teacher educators and pre-service EFL student teachers. We conducted classroom observations to verify part of the interview data and gather more data to inform the research phenomenon better. Also, we carried out document analyses of teacher educators' lesson plans and analyses of students' pedagogical diaries to further enrich interview and observation data. Data display was accomplished by displaying interview and observation data in excel matrixes. The central research question guided the matrixes, sub-research questions, interview questions, observation categories and indicators, coding processes, and existing published research that supported findings. Table 1 illustrates the components of the matrixes. Data condensation was done by using manual In Vivo coding and Pattern Coding, as explained by Miles, Huberman, \& Saldana [32]. Finally, we applied conclusions drawing and verification to further analyze In Vivo and Pattern coding from a thematic perspective. In this state, we figured out a logical way to report the main findings. Also, we chose existing research that best supported the findings in this study. During the whole process of data analysis, we considered the four assumptions of transcendental phenomenology as elucidated by Creswell [26].

Table 1. Example matrix used for data display and analysis

\begin{tabular}{|c|c|c|c|c|c|c|}
\hline \multicolumn{7}{|c|}{ Central Research Question: } \\
\hline \multicolumn{7}{|l|}{ Sub-research Question 1: } \\
\hline \multicolumn{7}{|c|}{ Interview Question 1 or Field notes of observation 1} \\
\hline $\begin{array}{l}\text { Participants (Go by } \\
\text { pseudonyms) }\end{array}$ & $\begin{array}{l}\text { Interview } \\
\text { Transcriptions } \\
\text { Or } \\
\text { Observational Data }\end{array}$ & $\begin{array}{ll}\text { In } & \text { Vivo } \\
\text { Coding } & \end{array}$ & Pattern Coding & $\begin{array}{l}\text { Units of } \\
\text { Analysis }\end{array}$ & $\begin{array}{l}\text { Direct } \\
\text { Quotes }\end{array}$ & $\begin{array}{l}\text { Existing } \\
\text { Published } \\
\text { research to } \\
\text { support findings }\end{array}$ \\
\hline \multicolumn{7}{|l|}{ Participant 1} \\
\hline \multicolumn{7}{|l|}{ Participant 2} \\
\hline \multicolumn{7}{|l|}{ Participant 3} \\
\hline \multicolumn{7}{|l|}{ Participant 4} \\
\hline \multicolumn{7}{|l|}{ Participant 5} \\
\hline \multicolumn{7}{|l|}{ Participant 6} \\
\hline \multicolumn{7}{|l|}{ Participant 7} \\
\hline \multicolumn{7}{|l|}{ Participant 8} \\
\hline \multicolumn{7}{|l|}{ Participant 9} \\
\hline Participant 10 & & & & & & \\
\hline
\end{tabular}




\subsection{Rigor and Trustworthiness}

Securing rigor and trustworthiness in qualitative studies is essential. Rigor and trustworthiness in qualitative research refer to what quantitative research is called internal and external validity, reliability, and objectivity $[33,34]$. However, in this research, we used Lincoln and Guba [33]' qualitative criteria because of the nature of our study. The criteria are credibility, transferability, dependability, and confirmability. Credibility indicates internal validity; transferability, external validity; dependability, reliability; and confirmability, objectivity [33].

Hence, we secured rigor and trustworthiness as follows. Credibility and transferability were guaranteed using five techniques, namely, instrument pilot testing, triangulation, member checks, thick description, and direct quotes [35-38]. We created the structured interview protocols and pilot tested them. We used an EFL teacher educator and a pre-service student teacher as the sample to pilot test the interview protocols. The classroom observation protocols were not pilot tested because we did not find a classroom to do so. However, they were reviewed by two experienced EFL teacher educators. The observation protocols were further improved as we started to conduct the first classroom observation. That is, they were shaped as the data started to emerge. In addition, we secured triangulation of data collection methods. That is, we conducted structured interviews with EFL teacher educators and pre-service EFL student teachers. We conducted classroom observations and document analysis. Pursuing this further, we used member checks. That is, once we transcribed the interviews, we sent research participants the transcriptions via email for them to verify that the interview transcriptions had what they had expressed. Also, we used thick descriptions while reporting the findings. Lastly, the thick descriptions were supported with direct quotes from the data gathered.

As for dependability, we secured it using two techniques. We utilized team coding to augment the reliability of the results [32]. Also, we utilized purposive sampling to select the research site and the participants. That allowed us to collect meaningful data to inform the research problem.

Confirmability was secured by presenting results that only came from data collected. In other words, findings reported in this study represent participants' lived experiences about the research phenomenon. As evidence, we provided direct quotes drawn from the data to support findings $[35,34]$. Lastly, as researchers, we tried to bracket out our own lived experiences about the phenomenon [24]. That is, we tried to put aside our perceptions and biases regarding the research problem.

\subsection{Anticipated Ethical Issues}

Regarding ethical issues, we followed Creswell's [28] recommendations to avoid ethical problems. We requested permission in the target university to gather data. We did not use any deceiving mechanism neither to recruit nor to collect data. It means that our research informants knew from the very beginning the actual purpose of our investigation. We recruited research participants by using informed consent forms. They were aware that they could withdraw from the study at any time if they wish to do so. We also told them that part of the data we were collecting was going to be published; however, their actual names were going to be kept anonymous. In other words, we substituted actual names by pseudonyms to protect our participants' privacy. Finally, as we already mentioned, we used member checks of interview transcriptions, so research participants could verify that the information we were going to put in writing was what they said.

\section{Findings and Discussion}

This qualitative phenomenological study sought to examine the lived experiences of 10 EFL teacher educators and 10 pre-service EFL student teachers about the development of English teaching skills in courses designed to deliver English proficiency in a pre-service EFL teacher education program at a public university in Nicaragua. To conduct this inquiry and to inform the central research question, we set three sub-research questions, namely, 1) what is the theoretical rationale that motivated EFL teacher educators to teach English teaching skills in courses devoted to developing English proficiency in a pre-service EFL teacher education program? 2) what strategies do EFL teacher educators and pre-service student teachers use to develop English teaching skills in courses devoted to delivering English proficiency in a pre-service EFL teacher education program? 3) what benefits do pre-service EFL student teachers obtain from taking English proficiency courses in which EFL teacher educators provide overt pedagogical elucidations of teaching strategies and teaching activities?

Findings are presented in three major sections; each section corresponds to one of the sub-research questions. However, before we begin elucidating the findings of this study, we are going to present the pseudonyms that replaced the actual participants' names. The pseudonyms will be used as we discuss the results. Table 2 shows the pseudonyms and some demographic information about participants. 
Table 2. Participants' pseudonyms and some demographic information

\begin{tabular}{|c|c|c|c|c|}
\hline $\begin{array}{c}\text { EFL Teacher } \\
\text { Educators/Pseudonyms }\end{array}$ & $\begin{array}{c}\text { Years of } \\
\text { teaching } \\
\text { experience }\end{array}$ & $\begin{array}{c}\text { Courses he/she was } \\
\text { teaching }\end{array}$ & $\begin{array}{c}\text { EFL student } \\
\text { teachers/ } \\
\text { Pseudonyms }\end{array}$ & $\begin{array}{l}\text { Courses taken in } \\
\text { semesters I and II }\end{array}$ \\
\hline Participant 1: Ms. García & 15 & $\begin{array}{l}\text { Integrated English skills II: } \\
\text { reading and writing }\end{array}$ & Participant 1: David & \multirow{5}{*}{$\begin{array}{l}\text { English skills I: reading } \\
\text { and writing } \\
\text { Integrated English skills I: } \\
\text { Listening and speaking } \\
\text { English pronunciation I }\end{array}$} \\
\hline Participant 2: Ms. Rodriguez & 10 & $\begin{array}{l}\text { Integrated English skills II: } \\
\text { Listening and speaking }\end{array}$ & $\begin{array}{l}\text { Participant 2: } \\
\text { Margarita }\end{array}$ & \\
\hline Participant 3: Ms. Murillo & 7 & $\begin{array}{l}\text { Integrated English skills II: } \\
\text { Listening and speaking }\end{array}$ & Participant 3: Jose & \\
\hline Participant 4: Ms. Perez & 4 & $\begin{array}{l}\text { Integrated English skills I: } \\
\text { Listening and speaking }\end{array}$ & Participant 4: Alba & \\
\hline Participant 5: Ms. Gonzales & 3 & $\begin{array}{l}\text { Integrated English skills I: } \\
\text { Listening and speaking }\end{array}$ & Participant 5: Carlos & \\
\hline Participant 6: Mr. López & 20 & $\begin{array}{l}\text { Integrated English skills II: } \\
\text { reading and writing }\end{array}$ & Participant 6: Marvin & \multirow{5}{*}{$\begin{array}{l}\text { Integrated English skills II: } \\
\text { reading and writing } \\
\text { Integrated English skills II: } \\
\text { Listening and speaking } \\
\text { English pronunciation II }\end{array}$} \\
\hline Participant 7: Mr. Reyes & 10 & English pronunciation I & Participant 7: Gloria & \\
\hline Participant 8: Mr. Gomez & 8 & English pronunciation II & Participant 8: Roberto & \\
\hline Participant 9: Mr. Torrez & 5 & $\begin{array}{l}\text { English skills I: reading } \\
\text { and writing }\end{array}$ & Participant 9: Rosa & \\
\hline Participant 10: Mr. Fernandez & 5 & $\begin{array}{l}\text { English skills I: reading } \\
\text { and writing }\end{array}$ & $\begin{array}{l}\text { Participant 10: } \\
\text { Miriam }\end{array}$ & \\
\hline
\end{tabular}

Lastly, we want to inform readers that direct quotes from student teachers' interviews have grammatical inaccuracies. Grammatical inaccuracies are evidence that the English level of student teachers was in a developmental stage. We decided not to correct them because, based on our judgment as EFL teacher educators, those grammatical errors did not interfere with the meaning conveyed in the direct quotes.

\subsection{Theoretical Rationale to Deliver Teaching Skills in English Proficiency Courses}

This next section covers the discussion of the main findings of the theoretical rationale used by the target EFL teacher educators to deliver English teaching skills to pre-service student teachers in courses meant to teach English proficiency. Five units of analysis resulted from data gathered through interviews, classroom observations, and lesson plans analysis.

Findings demonstrated that one of the ways the target EFL teacher educators informed their teaching practices was through theories of second language acquisition. For example, Mr. Reyes expressed, "I've learned that all learning theories, like, behaviorism, constructivism, and cognitivism, have helped me in my teaching. I tell my students any time I teach that they need to think about how they teach and why they teach that way." Mr. Reyes set some examples of how he had used learning theories in his English classes. He said, "When I'm teaching pronunciation, I bring into my class videos or audio files recorded by native speakers and ask my students to mimic their pronunciation by repeating what they hear. Sometimes, I have them work in projects or to follow step-by-step processes to learn pronunciation."

In the same line of thought, Ms. Murillo added, "I always think about why I'm doing things in a specific way. Like, for example, sometimes I do what Krashen says. Like, making my students feel relaxed and having them practice a lot listening and speaking in my class."

Additionally, Ms. Perez stated that even though her classes are mostly learner-centered, she uses other language learning theories such as behaviorism and cognitivism to teach listening and speaking skills. She affirmed, "My English classes are centered on my students. They work in groups, do projects, study alone, but also practice a lot speaking by learning vocabulary and repeating them a lot. They have to memorize information to speak."

Lastly, Mr. López asserted that educators have to reason how to teach. That pedagogical reasoning includes analyzing language teaching and learning through learning theories. For instance, he stated, "In this teacher training program, all of us reflect a lot about our teaching. We've agreed that we have to explain to our students why we teach the way we teach, so we need to understand what we do first." A good example of what Mr. López said was observed in a lesson of his reading and writing course. At the beginning of that lesson, he told his second-semester students, "today, we're going to use a graphic organizer to summarize information from two reading passages. This graphic organizer is a top-down information processing activity. It's a cognitivist activity. We'll work with main ideas."

These findings found support in the existing body of research. For example, some EFL researchers found that teacher educators develop a conscious level of understanding and use of learning theories to inform teaching and learning practices as they become more and more experienced [3,4,6,8,9]. For instance, Mr. Reyes and Ms. Perez referred to learning theories such as cognitivism 
[21,39,40], behaviorism [41,42], and constructivism $[40,43,44,45]$. Ms. Murillo referred to Krashen's [46] monitor model, the input hypothesis, and the affective filter hypothesis [46]. Lastly, Mr. López talked about cognitivist information processing theoretical principles to process general ideas in reading passages $[21,47]$.

In short, out of those excerpts from the data, we can notice that research participants used language learning theories to inform their teaching. Among those language learning theories mentioned were constructivism $[40,43,44,45]$, behaviorism [41,42], cognitivism $[21,39,40]$, and some of the hypotheses of Krashen's[46] monitor model, the input hypothesis and the affective filter hypothesis. These results tell us two things. On the one hand, participants used language learning theories to inform their teaching practices. On the other hand, informants believed that there is not only one best learning theory to teach. That is, teaching may benefit from different learning theories depending on the learning situation or learning needs of students.

A second way how the chosen EFL teacher educators informed their teaching practices to help pre-service EFL student teachers develop teaching skills in English proficiency courses was through observational knowledge acquired when they were pre-service EFL student teachers. All research participants asserted that they vicariously learned some teaching strategies and activities from their professors. Then, when they taught for the first time, they retrieved part of that knowledge and used it to teach English. All of them said that at the onset of their career as EFL teachers, they informed their teaching based on observational knowledge they acquired indirectly from their professors. As they gained more EFL teaching experience, they commenced utilizing pedagogical knowledge and didactic knowledge they had been delivered in their teacher education programs. Evidence of these findings can be observed in the following excerpts from the data collected. Mr. Gomez expressed, "The first time I taught in my teaching practicum, I wasn't sure what to do. I ended up using activities that my teachers used in my English classes, like, songs, teaching with pictures, drills, and flashcards to learn vocabulary." In the same vein, Ms. García added, "I learned by observing when my teachers taught me English. When I began teaching, I remembered some strategies I saw my teachers using, so I used them too. For example, I had my students learn dialogs, word lists, and worksheets." Lastly, Mr. Fernandez stated, "Right after I graduated and went teaching, I felt like I didn't learn anything. So, I sort of replicated some of the activities my professors used. But I began to read again what I'd learned at school."

Some researchers found that what Mr. Gomez, Ms. García, and Mr. Fernandez experienced has been experienced by other novice English teachers. For example, they said that at the beginning, novice EFL teachers trust more in knowledge acquired indirectly through observation in their teaching education programs $[3,4,8,9,20]$. It means that novice teachers regain power over pedagogical knowledge, learning theories, and content knowledge as they become more experienced teachers $[8,20]$.

Pursuing this further, research participants said that as part of professional development workshops and reflections about finding ways to impart teaching skills to their pre-service EFL student teachers, they decided to take advantage of those lived experiences regarding observational knowledge. Therefore, they agreed that they were going to make indirect observational learning into active observational learning by delivering teaching skills in courses devoted to developing English proficiency. Their motivation to use that type of knowledge in their English courses came from the lack of teaching opportunities that pre-service student teachers had in the target teacher education program. To illustrate, Ms. Gonzales said, "We learned by observing our teachers when we were learning English, so in this program, we decided to help our students learn teaching skills by explaining the strategies and activities with which we teach." Additionally, Ms. Rodriguez stated, "we decided to help students learn teaching skills while learning English. We explain all the activities we use to teach. They take notes of those activities, and then they teach once or twice every semester in each course." In the same line of thought, Mr. Torrez expressed, "we have been graduating better teachers since we began giving students opportunities to learn to teach in their English classes. We have noticed the change."

Findings revealed as well that the decision participants made to use overt observational learning to develop teaching skills in the target EFL teacher education program was informed in research about observational knowledge. For instance, Ms. García affirmed, "from research, we learned that observational learning is called apprenticeship of observation. It's something that doesn't need to be taught. But making it more active in English courses, students learn to teach. It's worked for us."

In conformity with existing research, apprenticeship of observation has been identified as an essential source of knowledge from which language teachers construct part of their teaching knowledge and skills $[3,4,8,9,48,49,50]$. To some researchers, apprenticeship of observation refers to the knowledge student teachers acquire by observing their professors teaching $[3,4,8,9,48,49]$. What these researchers have found is that apprenticeship of observation does not require explicit teaching because this type of learning occurs basically by observing. However, participants in this study said that if apprenticeship of observation is done overtly, the knowledge acquired is more powerful than the knowledge student teachers may develop by merely passively observing their teachers. As we learned from the direct quotes presented above, the target EFL teacher educators turned observation learning into an overt learning process to develop teaching skills in 
courses that were designed to deliver English proficiency to pre-service EFL student teachers. The results showed that the integration of teaching skills development in English proficiency courses had helped teacher educators to prepare better English teachers in the target language teacher education program. Therefore, it appears that integrating more than one way of learning is beneficial for student teachers.

Another source of knowledge participants identified as a way to inform their theoretical rationale that motivated them to help pre-service student teachers develop teaching skills while acquiring English proficiency was what they called the integrated learning approach. According to $\mathrm{Mr}$. Fernandez, in the target EFL teacher education program, they found that integrating teaching skills development in English courses helped pre-service student teachers learn to teach the English language. He stated:

Students spend two years learning English in this program, so we decided to use our time better by teaching them how to teach. We use an integrated teaching approach because students learn more skills at the same time. In every English class that students take, we explain to them the purpose of each teaching activity we use in class. They learn how those activities are used to teach. Also, we have them think about the effectiveness of those activities. If they're first semester students, sometimes we allowed them to use Spanish to write their notes or to talk about the way we teach. But little by little, they begin using English only. The most important thing is that we allow them to choose some of those activities to teach demo classes to their classmates. That way, they learn to teach. When they begin taking pedagogical courses, they are more prepared as teachers.

Debriefing what Mr. Fernandez said, we can learn that the main reasons why they deliver English teaching skills in English proficiency courses are to maximize pre-service student teachers' learning. That is, as student teachers become proficient English users, they work on acquiring teaching skills as well by learning from the way their professors teach. Another indication of integrated learning can be appreciated in the name of some of the English courses we observed. For example, based on the course syllabi, we found that courses were named as "Integrated English skills." Those courses integrated at least two macro English skills such as listening and speaking and reading and writing. In the curriculum of the target EFL teacher education program, there were ten courses with that emphasis, five integrating listening and speaking, and five integrating reading and writing skills. Pursing this further, findings from the student teachers' interviews provided some evidence to support what Mr. Fernandez expressed. To give an example, Marvin affirmed, "Teachers always said us we need put attention how they teach us. They said us all activities they use. We need write a diary with good activities to teach one or two classes. It's nice. We learn teaching and English." Even though Marvin's utterances are not grammatically accurate yet, we can appreciate that student teachers have a clear idea of the EFL teacher educators' reasoning of fostering teaching skills development in their English courses. Marvin knows he will develop teaching skills as he learns English.

Some researchers have found that integrated learning is beneficial to language learners [51-55]. For example, integrating more than one English skill at a time when developing English proficiency may provide students with opportunities to be exposed to natural ways of learning English. That is, when people learn their first language, they do not do it through segregated skills, focusing on one single skill only. Instead, they apply all that is at their disposal. They use their senses to process bottom-up and top-down information. They listen for some time, and when ready, they speak. In academic settings, people may read and then write. Findings demonstrated that the target EFL teacher educators found a way to take advantage of English proficiency courses and overt observational knowledge to help pre-service student teachers develop teaching skills by applying the principles mentioned above.

More evidences to support the findings presented above came from document analysis data. In the analysis we conducted to lesson plans, we found that most of the target EFL teacher educators used Nation and Newton's [53] four strands integrated model to teaching English. To illustrate, in one of Ms. Rodriguez' lesson plans, when she referred to the teaching approach to teach that lesson, she wrote, "use Nation and Newton's listening and speaking teaching principles." We found that she also referred to the Common European Framework of Reference for Language Learning and Teaching (CEFR). The lesson plan indicated, "English level A2." Therefore, we can infer that the CEFR gave Ms. Rodriguez directions of the scope and sequence $[15,56]$ of her class and Nation and Newton's[53] four strands teaching model guided her on how to teach. At the same time, those pedagogical resources were passed on to student teachers. That was what we could hear and observe from a lesson that we videotaped in Ms. Rodriguez's class. She began her lesson by telling student teachers:

Today the input for this lesson is vocabulary. You'll learn and practice some words about restaurants. Then you'll listen to a conversation in English and will do some activities using those words. As homework, you'll prepare a conversation about your favorite restaurant in this city and will do it in the next class. I'll use Nation and Newton's teaching model that I explained before teaching this lesson.

Nation and Newton's [53] English teaching model consists of four components, which they called strands. These four strands are 1) meaning-focused input, 2) meaning-focused output, 3) language-focused learning, and 4) fluency development. Out of those four strands, it appears that Ms. Rodriguez used three of them; namely, language-focused learning, to teach vocabulary about restaurants; meaning-focused input, to further practice that 
vocabulary through listening to a conversation; and he used meaning-focused output, to have students create their own conversation and then perform it in class.

The last source of knowledge that research participants employed to inform their teaching practices to help pre-service EFL student teachers develop teaching skills was their lived teaching experiences with pre-service student teachers. Findings revealed that all participants concurred that understanding the knowledge, competences, and dispositions pre-service student teachers are to develop in EFL teacher education programs was a fundamental element that helped them inform the way they taught and what they taught. For instance, Ms. Murillo said, "As an educator, you need to really understand the knowledge, skills, and values that future English teachers need. That tells you what and how to teach." In the same line of thought, Mr. Torrez added, "Definitely, having a clear picture of the study plan and what it means helps us keep our teaching focused on what students need to become good English teachers." Lastly, Ms. Gonzales expressed, "Even when knowing what is expected in the curriculum, we need to look for ways to help students learn to teach. If we don't do something, students may graduate knowing about teaching, but not knowing how to teach." What these three participants said makes sense because sometimes teacher education curricula are content-driven; therefore, the teaching and learning process centers more on declarative knowledge than on practical knowledge [21]. From our experience as EFL teacher educators, we believe that there should be a balance between declarative and practical knowledge in pre-service teacher preparation programs.

According to the findings, that was the rationale behind the decision research participants made to incorporate an integrated approach focused on teaching pedagogical and didactic knowledge and skills in English courses to make a balance of what student teachers were learning. In other words, participants noticed that before imparting teaching skills in English proficiency courses, student teachers who graduated from the target teacher education program lacked teaching experience. It was found that the only time students practice declarative pedagogical knowledge was in a short practicum almost at the end of the program. To illustrate, Mr. Reyes conveyed, "I remember that some years ago, our students said many times that they didn't feel ready to teach after graduation. It was mostly because the teaching practicum in the curriculum is very short, only 60 hours." Additionally, Mr. Gomez stated, "observing the weaknesses and strengthens of the first generations of students who graduated from this program about teaching; we decided to create opportunities for them to start learning to teach as they were learning English skills. Finally, Ms. Perez said that the results of employing an integrated approach to teach English and teaching skills at the same time in English courses had worked well for them because now, when students graduate, they feel more prepared as English teachers. This excerpt exemplifies this finding, Ms. Perez expressed, "Giving students opportunities to learn to teach in their English classes has helped them a lot. When they graduate now, they show more preparation for teaching. We've seen that when observing teaching practicums and demo classes." Literature about curriculum delivery supports integrated approaches to teacher preparation. For example, Candrall [57] and Day[58] contended that curricula that deliver declarative and practical knowledge in a balanced way might provide student teachers with more opportunities to develop more robust teaching knowledge and competences. 


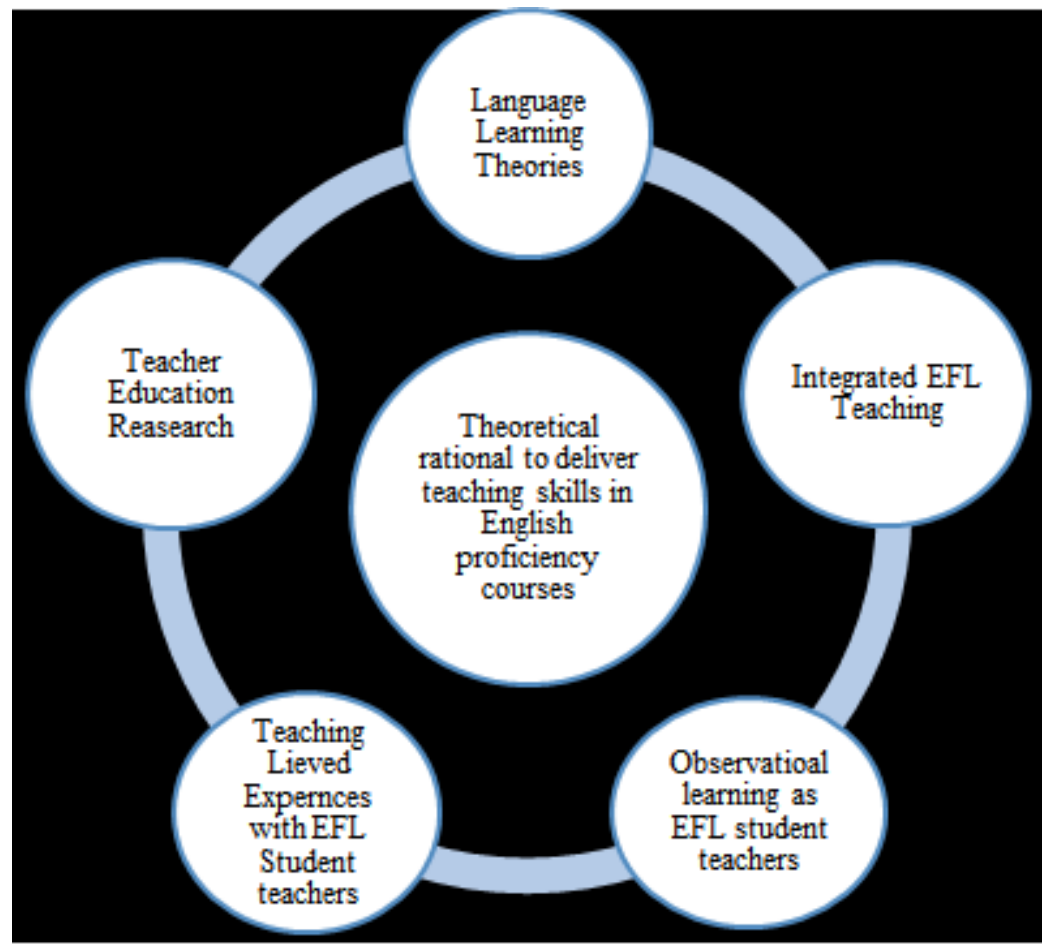

Figure 1. EFL teacher educators' theoretical rationale to deliver teaching skills in English proficiency courses

\subsection{Strategies to Deliver Teaching Skills in English Proficiency Courses}

This next section addresses the strategies employed by the EFL teacher educators who participated in this study to deliver teaching skills in courses devoted to developing English proficiency. We report here a major unit of analysis that emerged from the data gathered. That unit of analysis was named teaching English skills to pre-service EFL student teachers in English proficiency courses. However, this unit of analysis entails other sub-themes embedded in it.

According to the document analysis we conducted, the curriculum of the target EFL teacher education program stated that pre-service student teachers who enter the program not knowing how to speak English had to spend the first two years of their teacher preparation learning English. The target level to develop in these two years was approximately a C2 English proficiency before taking other courses related to pedagogy, didactics, and other areas of education. The target English proficiency level was expected to be acquired in 1,216 hours of direct instruction in the EFL teacher education classroom.

In this scenario, interview findings revealed that since some generations of student teachers who graduated from this program lacked teaching skills, participants decided to help student teachers develop teaching skills by setting themselves as teaching models. That is, they decided to make passive observational learning, commonly referred to in the literature as vicarious learning $[59,60]$ or as apprenticeship of observation [48-50], an active way of learning in the classroom. In general, this study demonstrated that the research participants turned observational learning into an active learning strategy to foster the development of teaching skills in English proficiency courses.

Figure 2 shows seven steps that the target EFL teacher educators followed to help student teachers grow teaching skills in English courses. The following excerpts from the data illustrate these seven steps of active observation learning.

Mr. López expressed:

When I'm teaching, I act as a role model. I like to have my students keep a pedagogical diary in which they can take notes, think about those notes, write about some teaching activities and strategies I use, say which of those activities they would use and why. I always tell them that I learned many things from watching my professors. I call their attention to see how I teach. I like to explain each activity I use at the beginning of each class. Out of all the activities or strategies I use, my students have to write down at least one of them, the one they like most. I ask them to write a short paragraph saying why they like it, what they would change, and how they would use it. Also, I allow them to discuss in groups what they write in their diaries. Twice a semester, they have to teach demo two demo classes using some of those strategies. We have found this way of teaching very good for students to learn some teaching skills while they learn English.

As well, Mr. Gomez added:

My students know that they have to observe how I teach English pronunciation. Like, for example, they observe me and take notes of the strategies and methodologies I 
use. In this program, we teach our students from the very beginning to create a diary about teaching strategies. They use it when they have to teach their two demo classes in each English course. We do this to teach English skills. In the past, some students said their teaching skills were not strong. So, we decided to use our English courses to help our students learn some teaching knowledge. So by the time they begin taking more advanced courses, they already know some teaching skills. I also ask my students to think about how they would use the activities I use to teach them pronunciation. Some of them have great ideas. And they show it when teaching their demo classes. We like to teach this way. Students learn from us, and we learn from them too.

In the same vein, Ms. García said:

In my reading and writing class, I have my students write what we have called 'pedagogical diary.' They know what that is when they take my class. They learn about it in their first English courses they take in the first semester. Basically, students listen to my pedagogical explanation of the strategies and methodologies I use to teach, observe me, take notes, think individually about their notes, participate in group discussions, and then in groups prepare and give two demo classes to teach their classmates reading or writing skills. I provide feedback and support in the discussions and classes.
Lastly, Mr. Fernandez stated, "sometimes, some students come to me and say they have learned a lot the way I teach. I always explain to them each activity I use, like, the steps, the procedures, the purpose of the activity, and when it could be used." Additionally, he added, "Over the years, we've seen that incorporating teaching skills in English courses was a good decision. Students learn some teaching skills little by little as they learn English."

In short, as exemplified in the previous direct quotes, findings demonstrated that participants followed seven steps to impart teaching skills to pre-service student teachers in English proficiency courses. First, they provided an elucidation of the target teaching and learning strategies they were going to employ to teach their English classes. Second, they implemented those strategies. Third, students actively observed the implementation of the target strategies as their professors taught them English. Fourth, student teachers used what participants called 'pedagogical diaries' to keep records of those strategies or activities they considered more useful for their future teaching in demo classes. Fifth, students were given some time to reflect individually on the teaching strategies used by their professors. Sixth, students were given some time to discuss in groups the weakness and strengths of the strategies used. Lastly, twice a semester, student teachers used some of those strategies in demo classes they taught in their English courses. Figure 2 summarizes these stages.

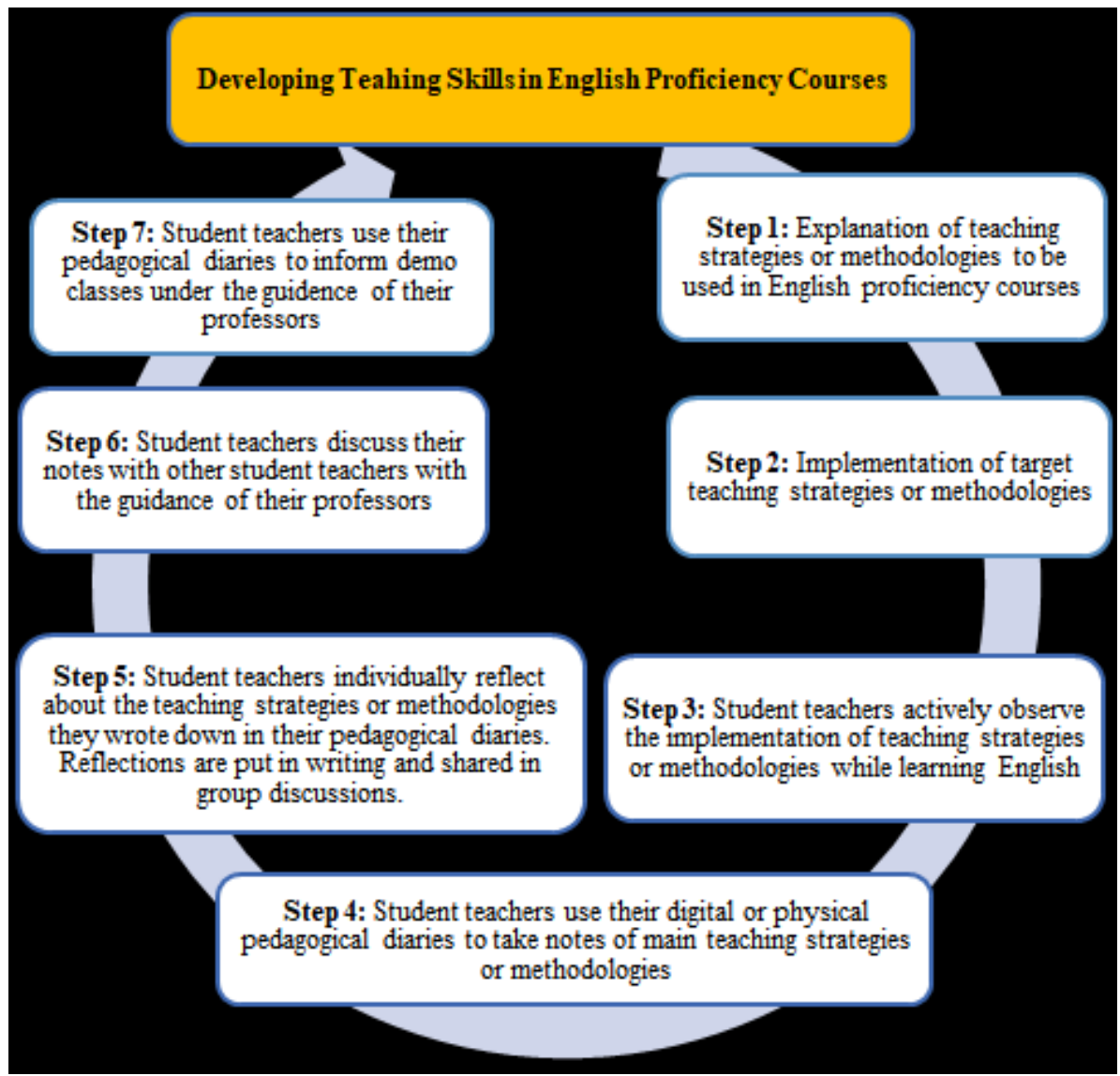

Figure 2. Developing teaching skills through active observation learning in the EFL teacher education classroom 
Classroom observation data further supported the interview findings above. Figure 3 below exemplifies the integrated approach the target participants employed to help student teachers develop EFL teaching skills in courses devoted to teaching English proficiency. The picture was taken in Mr. Gomez's pronunciation class.

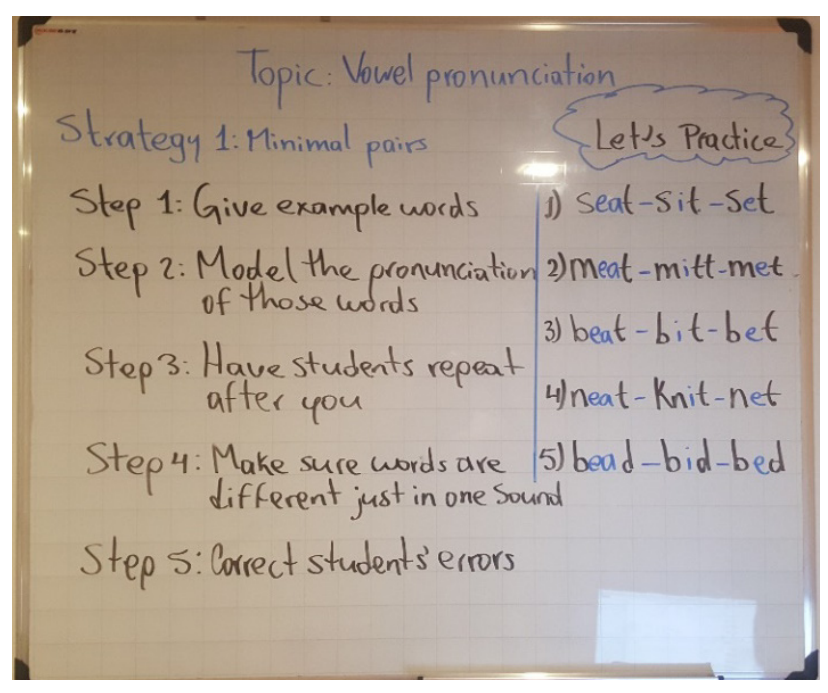

Figure 3. Evidence of how participants integrated pedagogical knowledge development in English courses

For example, in Mr. Gomez's pronunciation class, we observed that he devoted ten to fifteen minutes of his two-hour class to explain the teaching and learning activities he was going to use. As can be appreciated in Figure 3 above, he provided students a step-by-step elucidation of the procedures of the target teaching strategies, in this very case, using minimal pairs to teach three English vowel sounds, namely, $/ \mathrm{i} /$ as is 'seat', $/ \mathrm{I} /$ as is 'sit', and $/ \varepsilon /$ as is 'set'. As well, Mr. Gomez explained the purpose of using minimal pairs to help students develop pronunciation skills. As the explanation was given, students asked questions and took notes about what $\mathrm{Mr}$. Gomez was saying. After the pedagogical elucidation, $\mathrm{Mr}$. Gomez proceeded to apply the teaching strategy "minimal pairs' to teach the target vowel sounds to his students. By the end of the class, Mr. Gomez gave students about five minutes to organize their notes. He added a final comment reminding students to get ready to share their insights about his teaching in the next class.

After Mr. Gomez's pronunciation class finished, we conducted a short follow-up interview with Mr. Gomez. The follow-up interview with Mr. Gomez was to find out more about the theoretical rationale Mr. Gomez used in his class. As researchers and EFL teacher educators, we observed that the pedagogical explanation Mr. Gomez gave to students revealed only some of the theoretical pedagogical knowledge Mr. Gomez had. That is, based on observational data, we thought there should be something more in-depth in terms of theoretical knowledge that was not conveyed to student teachers in that specific pronunciation lesson; therefore, we thought it would be interesting to examine what that theoretical rationale was and why it was not shared with student teachers.

Consequently, we asked Mr. Gomez whether or not he considered the pedagogical and didactic elucidation given to students was deep enough, theoretically speaking. He responded that the pedagogical explanation he provided was adapted to the level of pedagogical understanding of student teachers. To illustrate, Mr. Gomez stated:

As you could see, what I told students about how to use minimal pairs to teach pronunciation was just basic teaching tips. They're second-semester students. Even though we want them to learn how to teach while they learn English, we do it little by little. Later, in the program, they'll learn go deeper in analyzing L2 learning theories.

Further, to continue with the interview, we related to the target EFL teacher education curriculum and said to Mr. Gomez, "the curriculum states that student teachers take the course 'Second language learning theories' in the fifth semester." How would pedagogical explanations be different if they were given to fifth-semester student teachers? He responded:

Well, in that case, the whole picture changes. I've taught that class a couple of times. I've found that bringing cases to be discussed and analyzed helps students internalize learning theories. Sometimes, I bring pictures and videos to explain how English is learned. Sometimes, those pictures and videos are taken in my own classes. We try to make student learning meaningful and applied to their own realities. So, if that explanation I gave today was for fifth-semester students, I would've mentioned the learning theories that were behind my explanation.

We asked again. What do you mean by that? Mr. Gomez replied:

For example, I would've guided my students to learn that there were two main learning theories behind the minimal pairs teaching activity. Like, for example, cognitivism and behaviorism. Why cognitivism? Because I presented some steps about how to use minimal pairs to teach the three sounds of the lesson. First, I wrote five simple steps to follow. The steps were ordered logically. But now that I think better, I think step four would've been put second. But, you know, we learn every day. I'll tell my students about that next class. Also, cognitivism was used because the input given to students was expected to be memorized, and little by little, students will start using it naturally. So, when teaching, I think about previous knowledge my students have to help them learn better. Like in the case of today's lesson, students learned how to pronounce each of the three vowel sounds, practice the pronunciation, and little by little, they will pronounce those sounds in other words in other contexts. Now, behaviorism was used too. I used audio-lingual principles. I had students repeat until I thought they've learned the pronunciation of the words I 
wrote on the board. I corrected their errors too. As you saw, I did it by correcting errors directly. The idea was that they learn a clear pronunciation of those sounds. That's important. So, going back to your question, that's how I would help students to think about the theories we use to teach English. It's easier now because students learn some teaching skills before taking learning theories. So we use their knowledge as a departing point to analyze how we learn English.

These direct quotes from the data revealed that the level of pedagogical knowledge and reasoning that student teachers acquire in courses devoted to developing English proficiency is less deep than the pedagogical reasoning acquired in more advanced pedagogical courses such as "Second language learning theories." Mr. Gomez exemplified this fact as he elucidated how cognitivism and behaviorism informed his pedagogical and didactical reasoning. Further, it seems that Mr. Gomez valued a lot the work of short term and long term memory. On the one hand, he used a behaviorist perspective to teach English pronunciation [39,40,61]. He focused on repetition, imitation, behavior formation, and error correction to help students ameliorate their English pronunciation until they develop an intelligible level of pronunciation [39,40,61]. In some way, Mr. Gomez also used the noticing principle of information processing to correct students' pronunciation errors. During the classroom observation, we noticed that he would address error correct at the moment they occur [62]. We observed that there were some instances that students would correct themselves. It appears that that happened as a behavior learned as a result of Mr. Gomez's error correction way.

On the other hand, Mr. Gomez utilized a cognitivist perspective to elucidate the logic of how he presented the target language input. For example, he mentioned three steps, namely, "students learned how to pronounce each of the three vowel sounds, practice the pronunciation, and little by little they will pronounce those sounds in other words in other contexts." Based on information processing theories, step one correspond to the cognitive stage of learning, which has to do with the procedural elucidation teachers provide to carry out a task, in this very case, the pronunciation of the vowels $/ \mathrm{i} /, \mathrm{II}_{\mathrm{I}} /$ and $/ \varepsilon /[21,63]$. Step two corresponds to the associative stage of learning, which deals with practicing the target language input [21,63]. Finally, step three corresponds to the autonomous stage of language learning in which learners are expected to produce the target input automatically by retrieving it from the long term memory and applying it when necessary $[21,63]$.

Additionally, the collected more evidence of pedagogical dairies by asking Roberto to share with us the part of his pedagogical model that contained the notes he took in Mr. Gomez's pronunciation lesson. We did this to corroborate whether or not student teachers kept a pedagogical journal as revealed by findings from interviews to the target EFL teacher educators. Therefore, after we interviewed Mr. Gomez, we asked Roberto to let us take a picture of the part of his pedagogical diary where he had taken the notes corresponding to Mr. Gomez's pronunciation class we observed. Since he was keeping a digital diary, he shared it with us as a Word file via email. Table 3 displays an excerpt from Roberto's pedagogical diary about the minimal pairs teaching strategy. This piece of data confirms that student teachers used a pedagogical diary to write down and reflect on teaching activities and strategies used by the target EFL teacher educators where this study took place. Grammar errors and sentence structure errors were kept as in the original data. That is an indicator Roberto's English proficiency level is a developmental stage yet. That makes perfect sense because Mr. Gomez's pronunciation class was considered an A2 level class.

Table 3. Excerpt from a pedagogical diary created by a research participant

\begin{tabular}{l} 
Class Notes \\
Course: English Pronunciation II \\
\hline Topic: Vowel pronunciation Teaching strategy: Minimal pairs \\
The teacher say minimal pairs are five steps, he write in the \\
whiteboard \\
He say this activity is to make difference of sounds \\
Step 1 - Give example words \\
Step 2 - Model the pronunciation of those words \\
Step 3 - Have students repeat after you \\
Step 4 - Make sure words are different just in one sound \\
Step 5 - Correct students' errors \\
Content \\
Seat- sit-set -- Meat-mitt-met -- Beat-bit-bet -- Neat-knit-net -- \\
Bead-bid-bed \\
The teacher say all the words -- We say all the words -- Repeat many \\
times \\
The teacher help we -- We practice by groups and in one \\
My reflection \\
I like this strategy, It's good. Steps are easy, Students practice a lot \\
pronunciation. They speak English like the teacher. I think it's good \\
to give the meaning in Spanish of the words. Students learn the \\
pronunciation and understand the words too. But how to choose the \\
words? I think it is hard that. Maybe I use a dictionary. \\
Should I use it or not in my demo classes? Yes, because it's good \\
Question to talk in the group: How to choose words with the \\
sounds? \\
My answer: use a dictionary
\end{tabular}

\subsection{How Did Participants Define a Pedagogical Diary?}

As illustrated by findings previously presented, one of the main components employed by the target EFL teacher educators to help student teachers build teaching skills in English proficiency courses was what they called "pedagogical diary." But what is a pedagogical diary in the first place? In this next section, we present an illustration of how participants defined a pedagogical diary.

According to participants, a pedagogical diary is a digital or physical record pre-service EFL student teachers kept of teaching activities and strategies EFL teacher educators used to teach English proficiency competences. Pedagogical diaries, according to findings, were used for 
student teachers to construct pedagogical knowledge and teaching skills as they were acquiring English proficiency competences. These findings can be exemplified in this direct quote from Ms. Murillo's interview data as she affirmed, "a pedagogical diary is a physical notebook or a digital word document that our students to create with teaching activities or teaching strategies we use to teach English skills. The idea is for them to learn to teach, as well." Another element that contributed to the development of pedagogical knowledge was that students had to reflect on the notes they took in their pedagogical diaries. In this regard, Ms. Rodriguez said, "my students have to think about what they write in their diaries critically. They have to say why they think an activity or strategy was good or bad. And say why they would use it or not".

Pursuing this further, in the classroom observations we conducted, we found that student teachers in each English course had either a notebook or digital file in which they wrote about teaching activities and strategies used by their professors. Further, Margarita and David, two of the student teachers who participated in this study, said that it was their first semester in the target teacher education program and that their English professors had had them create a pedagogical diary to construct teaching knowledge and skills by writing and reflecting on how their professors taught. They also asserted that they had to teach two times that semester in each English class. To illustrate, Margarita expressed, "my teachers said me to use my computer or a notebook. I put activities I like. My teacher teach. It's good. I say in Spanish if I like the activities. We talk with other students. We teach two little classes in groups in my courses." Additionally, David said, "in English class, we learn English, and we teach too. We write notes of the activities teachers use with us. I like. I learn teaching and English. My diary is in my computer. It's hard but good." We would like to highlight that grammatical errors in students' utterances were not fixed; that is, we decided to present the direct quotes as found in the data because that was an indication that students' English level was in a developmental stage. To be consistent with our research method, phenomenology, presenting the direct quotes as they emerged from the data was a way to give voices to our participants.

As for research to support these findings, we did not find any studies that addressed and used the term 'pedagogical diary' as an active apprenticeship of observation learning strategy. However, if passive observational learning is a useful source to inform pedagogical and didactic practices of novice teachers [48-50], we agree with the findings of this study, which revealed that active observational learning recorded in a pedagogical diary might also help to in-service teachers to learn to teach. It is because EFL student teachers make passive observational knowledge from observing their English teachers teaching an active process by keeping records of strategies and teaching activities, by reflecting on those teaching strategies and activities, and by implanting them in demo classes.

\subsection{Steps to Create a Pedagogical Diary}

This next section covers the steps student teachers followed in writing a pedagogical diary. Findings revealed that there were five steps to create a pedagogical diary. First, student teachers had to select either to create a digital or physical diary. Second, they had to pay attention to pedagogical explanations provided about their English teachers regarding their teaching, observe them while teaching, and write down procedures and purpose of teaching activities and strategies used to teach English communication skills. Third, they had to put in writing their reflections about teaching strategies they liked most. Fourth, they had to discuss in groups their notes and reflections. Lastly, after group discussion, student teachers had to reflect again individually and write whether or not they would use those teaching activities or strategies in their demo classes. Figure 4 summarizes these steps.

Direct quotes from the data illustrate these findings. For instance, Ms. García affirmed:

The pedagogical diaries pretty much follow these steps. If the students are first semester students, they are taught how to create a pedagogical diary, either using a computer or using a notebook. Then, students are advised to pay attention carefully to the explanations English teachers give about the strategies they use to teach English skills. They also told to take notes about teaching activities. The ones they like most. Then, they need to think about the effectiveness of teaching activities. If their English is not that good, they can write in Spanish. But they are encouraged to use English as much as they can. If they can say just one word in English, then we ask them to use it. What we look for is for them to learn English and get some knowledge about teaching. We also give students opportunities to discuss their notes in groups and to teach demo classes.

Additionally, Mr. Fernandez said, "students take notes, get into groups to discuss and share ideas about their notes, say why they think an activity is good or not; say if they would use certain activities; and if possible, say what they would change." Some language researchers and educators partially supported these findings as they said that one way to construct reflective teaching skills is by using written accounts and self-reflection of experiences [64-66]. As for this study, the types of experiences that student teachers were keeping on records using pedagogical diaries were teaching experiences they observed from their professors, which was expected to help them accrue pedagogical and didactic knowledge as they were learning English communication skills. 


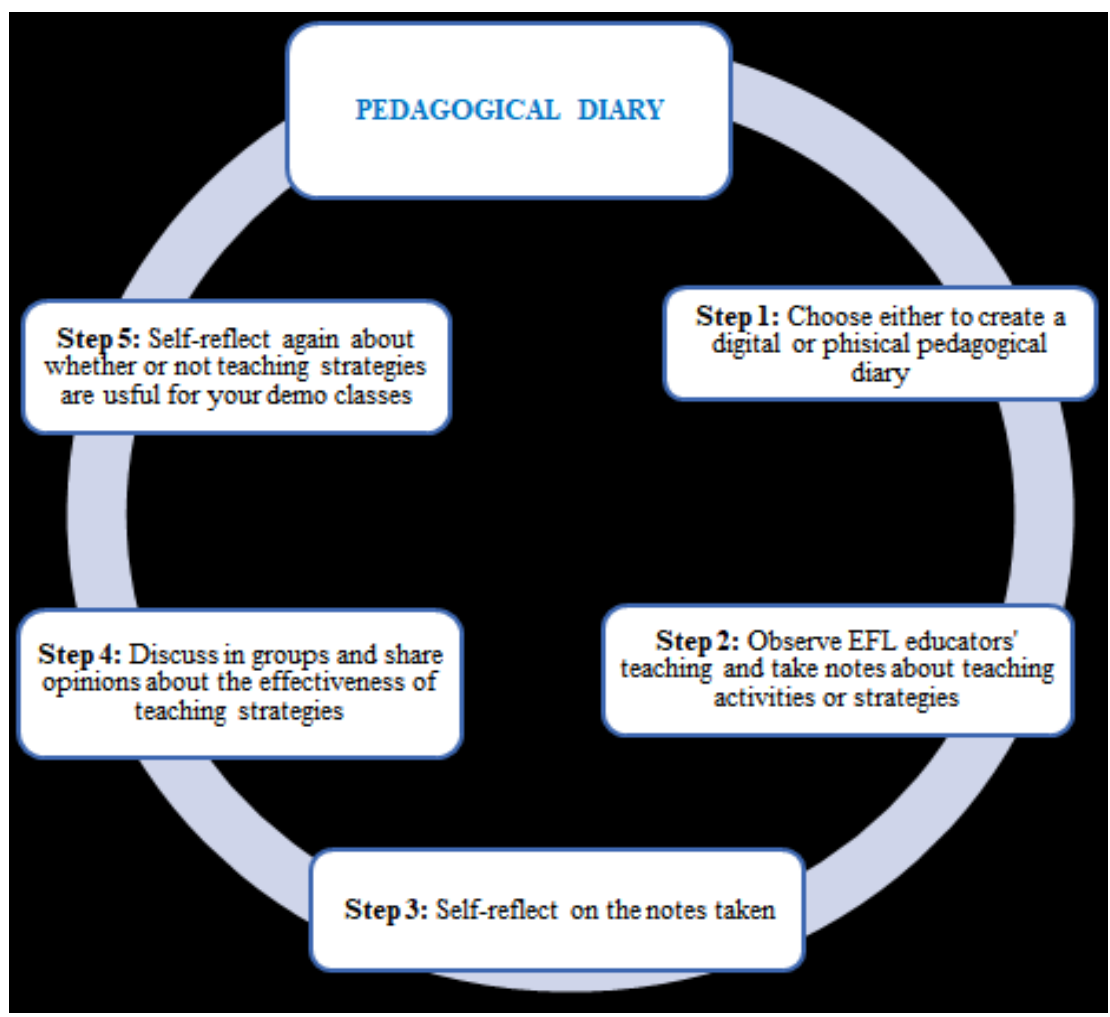

Figure 4. Steps to create a pedagogical diary to construct English skills in pre-service EFL teacher education programs

\subsection{Purpose of Creating Pedagogical Diaries}

This section addresses the purposes why pedagogical diaries were chosen as a tool for student teachers to build pedagogical knowledge and accrue teaching skills at the same time they learned English communication skills in the target EFL teacher education where this study took place. Mr. Reyes, for example, said, "Basically, a pedagogical diary allows students to acquire knowledge about how to teach English. At the same time, they practice writing in English. Regarding this matter, Ms. Perez added, "I haven't done research about this, but pedagogical diaries help students practice their English writing and vocabulary learning. They learn to think like teachers, too. I've seen some students use their pedagogical diaries even when they do their practicum.

Pursuing this further, student teachers concurred with what EFL teacher educators said regarding the purposes of creating pedagogical diaries to develop pedagogical and didactic knowledge. According to findings from interviews with student teachers, student teachers stated that pedagogical diaries allowed them to grow pedagogical knowledge and further practice English skills such as writing, grammar, and vocabulary development. For instance, José expressed, "In my diary, I practice to write English, vocabulary too. Of course, I learn activities to teach English." In the same vein, Alba added, "We write diaries to learn teaching activities. But we practice English too. Finally, Carlos said, "Diaries are good. We learn vocabulary, grammar, and writing. But we write about activities we practice in demo classes." Figure 5 summarizes the primary purposes of employing pedagogical diaries to help student teachers construct pedagogical knowledge and teaching skills. 


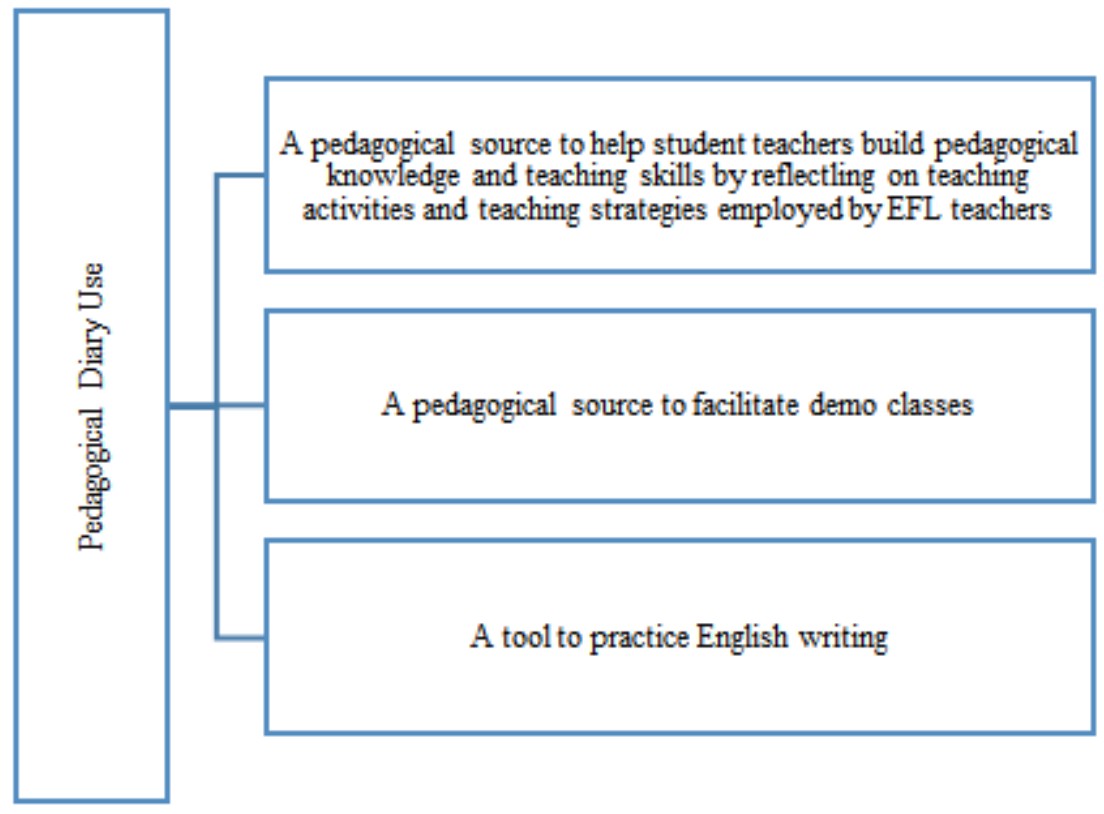

Figure 5. Use of pedagogical diaries

\subsection{Benefits of Delivering Teaching Skills in English Proficiency Courses}

The last research question that guided this qualitative phenomenological study had to do with the benefits pre-service student teachers obtained from teaching skills delivery in English proficiency courses in the target EFL teacher education program. According to findings, teacher educators and student teachers identified six main benefits from the integration of pedagogical knowledge and teaching skills development in courses devoted mainly to English proficiency acquisition. One of these benefits was the development of pedagogical knowledge. Findings revealed that this knowledge was accumulated as EFL teacher educators provided pedagogical elucidations of the teaching strategies and activities they utilized to teach English. To illustrate, Mr. López said, "Our student teachers acquire pedagogical knowledge as we explain theoretically the teaching and learning strategies we use to teach English." Similarly, Gloria, a first-semester student teacher, expressed, "In English courses, I learn English and about teaching." However, the level of the theoretical pedagogical explanations is adapted to the students' learning level. In other words, even though pedagogical and teaching skills are one of the primary goal teacher educators seek to develop in English courses besides English skills development, this knowledge is tackled step by step: it is strongly stressed when student teachers begin taking pedagogical and didactic courses. As illustrated previously, Mr. Gomez said, "Even though we want them to learn how to teach while they learn English, we do it little by little. Later, in the program, they'll learn go deeper in analyzing L2 learning theories."

A second benefit student teachers had as a result of the integration of teaching skills in English proficiency courses was the construction of teaching skills. According to the findings, this type of knowledge was built in two ways. First, student teachers observed their teachers applying teaching strategies and teaching activities to teach English; for instance, the minimal pairs strategy used by Mr. Gomez to teach English pronunciation. Second, student teachers acquired teaching skills as they implemented some of the teaching strategies and activities in demo classes. That is, to accomplish this goal, student teachers were required to teach twice each semester by applying teaching strategies used first by their professors in English classes. As a result of teaching demo classes, student teachers also grew lesson planning knowledge, classroom management knowledge, and time management knowledge. To illustrate, Mr. Torrez affirmed, "Besides learning English, students learn teaching skills. They observed us teaching English, use their pedagogical diary to record teaching strategies, and later use them to teach English to their classmates." In the same line of thought, Rosa, a first-semester student teacher, asserted, "we learn teach in English class. We see teachers when teach. And we teach two times in every English course." Research supported these findings as it has been found that teaching experience at any level is constructed as a novice, and experienced teachers start teaching and reflecting in their teaching practices $[5,6,9,10,20]$.

The third benefit student teachers obtained from the integration of teaching skills in English proficiency courses was the construction of content knowledge. The results of this study showed that this type of knowledge was developed as students had to learn some components relating to the English language such as grammar, vocabulary, pronunciation, reading skills, and writing skills. For instance, Mr. Fernandez stressed, "We've seen that students benefit from this way of teaching by improving their knowledge of grammar, pronunciation, 
and vocabulary because they study and learn better what they teach in demo classes." In support of what Mr. Fernandez conveyed, Marvin, a second-semester student, expressed, "I like demo classes. I learn more vocabulary, practice my grammar and pronunciation, and speaking. I learn to create lessons too." Researchers and educators found that content knowledge of English courses such as grammar, vocabulary, pronunciation, writing, and reading develops as English teachers become more and more experienced teachers because it is expected that if teachers do not know the content they will teach, they will learn that content before teaching it $[5,6,9,10]$.

Self-confidence growing as future teachers was another benefit student teachers obtained from the delivery of teaching knowledge and skills in English proficiency courses. The findings indicated that as student teachers begin teaching demo classes, their confidence to teach also grows. It is because pre-service student teachers accrue content knowledge, pedagogical knowledge, knowledge of their classmates, and knowledge of teaching. At the begin student teachers feel nervous when they teach demo classes for the first time; however, as they advanced from one semester to the other, they gain more confidence to teach English in demo classes. For example, Miriam, a first-semester student, said, "Demo classes are good, but I'm nervous teaching. This is my first semester, I teach one time before in this class." Further, Margarita and José, a second-semester student, supported these findings. Margarita stated, "Demo classes were difficult last semester, but now I think is easy. Not easy, easy, but more easy. Additionally, José expressed, "I feel more relax now teaching. I kind of know how do it now. I speak better and know more English." Furthermore, results indicated that self-teaching efficacy has to do with the support student teachers receive from their professors. To illustrate Alba said, "my teacher help we much. She help we with activities and English." In the same vein, Rosa added, "our teachers are good, nice. They said us how teach English. When I no understand a activity, I ask they." According to some researchers, confidence towards teaching English is gained as novice teachers construct teaching experience, mostly when teaching experiences are successful $[3,4,8]$. Further, it has been found that self-efficacy in academic settings is related to positive or negative lived experiences [67-69]. In this regard, we assumed that student teachers might have accumulated positive experiences when teaching their demo classes and when receiving feedback from their professors.

As well, oral English skills development was another benefit student teachers obtained from the delivery of teaching knowledge and skills in English proficiency courses. We found that the integrated approach to teaching English and teaching skills at the same time encourages students to practice productive oral English skills when students participate in group discussions about teaching strategies and when delivering demo classes. That is, the fact that students have to use English as a means of instruction when teaching their demo lessons makes student teachers improve their English speaking level. To exemplify, Ms. Gonzales affirmed, "Demo classes are great opportunities for students to practice their English speaking. Since they want to show their classmates that they are well-prepared, they practice a lot before and during the demo class. David, a second-semester student, agreed with Ms. Gonzales as he stated, "demo lessons push me to speak better. I practice a lot before my lesson. I do my best in my lesson." These findings found support in the literature as well as it has been found that the more you practice a language skill such as speaking, the better you become at it [6,53]. Of course, Nation and Newton [53] said that the conditions for language skill development need to be created; otherwise, if the conditions are adverse to learners, the target skills may not be developed. In the case of this study, it seems that student teachers were offered the conditions they needed to grow both oral English skills as well as teaching skills.

The last benefit student teachers receive as a result of using an integrated approach to teaching English and pedagogical knowledge in English proficiency courses is the fact that pedagogical diaries developed by student teachers are used as pedagogical and didactic sources for future teaching. To illustrate, Ms. Murillo said, "Students use pedagogical diaries not only for demo classes but also in their practicum. Some of them even use them when they just begin teaching in schools. Mr. López also asserted, "In practicums, I've seen that my students use their pedagogical diaries to look for activities they could use to teach their students. Further, student teachers confirmed this finding. They said that some of their classmates who graduated from the same program used their pedagogical diaries to teach in their teaching practicum and in the schools where they obtained their first teaching jobs. For instance, Miriam expressed, "my friend got a job in a school. She no have books. So, she use her diaries. She copy activities for students." Additionally, Marvin stated, "my friend from the tenth semester use his diaries in other classes, like the practicum. I think I will use my too." Even though current research did not mention pedagogical diaries as a source of pedagogical knowledge construction or as a source to inform teaching, research has found that teachers tend to revisit teaching materials to reuse them in other teaching settings and situations $[3,4,6]$.

In short, findings demonstrated that not only teaching pedagogical knowledge and teaching skills can be developed by using an integrated approach to deliver teaching English skills and English teaching skills in courses devoted to developing English proficiency, but student teachers can build other types of knowledge as well. For example, student teachers may gain some knowledge about time and classroom management. Demo classes provide students opportunities to practice further English skills such as speaking, vocabulary development, fluency, 
pronunciation, and writing. Student teachers also increase their confidence level to teach.

\section{Conclusions}

This qualitative phenomenological study concludes that pedagogical knowledge and teaching skills can be developed in English proficiency courses. According to the findings, the target EFL teacher educators utilized an integrated approach to teaching both English proficiency skills and teaching skills. The integrated teaching approach had to do with keeping records of teaching strategies and teaching activities employed by teacher educators to teach English communication skills. These records were kept by pre-service student teachers in what participants called "pedagogical diaries." Further, student teachers used their pedagogical diaries to reflect upon teaching strategies and as a source to inform demo classes. Pedagogical diaries, individual and group reflections, and demo classes were three essential ingredients of the integrated teaching approach. Teaching skills were promoted following seven main steps. First, EFL teacher educators provided pedagogical explanations of teaching strategies they used to teach English proficiency skills. Second, student teachers actively listened to those elucidations and observed the implementation of the teaching strategies while learning English. Third, student teachers kept records of teaching activities and strategies using their digital or physical pedagogical diaries. Fourth, student teachers individually reflected on the teaching strategies used by their professors and wrote down in their reflections in their pedagogical diaries. Fifth, student teachers discuss their notes with other student teachers with the guidance of their professors. Sixth, student teachers used their pedagogical diaries to inform demo classes under the guidance of their professors. Lastly, after teaching demo classes, student teachers reflected again on what worked and what did not work.

Further, this study concludes that the target EFL teacher educators came up with the idea that integrating teaching skills in courses devoted to developing English proficiency would help student teachers acquire some teaching knowledge and skills. This idea resulted from observing previous generations of student teachers who graduated from the target EFL teacher education program with weak teaching skills. Consequently, they said that they took advantage of what the existing literature calls apprenticeship of observation to help pre-service student teachers acquire pedagogical knowledge and teaching skills while they were learning English. However, these language educators did not integrate apprenticeship of observation as defined in the existing research, in which apprenticeship of observation is seen as a passive and unconscious observational learning process. Instead, they made passive observational learning an active and conscious way of learning by informing student teachers that they could develop some teaching knowledge by observing them on how to teach English. As well, this study concludes that the chosen language educators informed their rationale to integrate teaching skills delivery in English courses in various sources, for example, language learning theories, other integrated EFL teaching approaches, apprenticeship of observation, teaching lived experiences, and teacher education research.

Additionally, this study revealed that student teachers found that constructing teaching skills and learning English at the same time is a challenging process; however, this process becomes easier and easier as they advanced in their major. That is, they accumulate teaching skills in each English course they took. In each course, student teachers had two opportunities to teach a semester.

Lastly, this study found that the level of understanding of the pedagogical and teaching knowledge that teacher educators delivered to student teachers through pedagogical elucidations and demo classes in English proficiency courses is adapted to the level of understanding of students. That is, student teachers develop deeper pedagogical reasoning when they take more advanced pedagogical and didactic courses, but English courses have been valuable spaces for students to start developing English teaching skills.

\section{Recommendations for Future Research}

We found that delivering English teaching skills through English proficiency courses by actively observing EFL teacher educators teach English might be a useful way to prepare better English teachers, mostly in those EFL teacher education programs which are course-driven and which do not offer student teachers that many opportunities to teach. However, we recommend conducting more research regarding this type of research because, based on the current literature on teacher training, this phenomenon has not been investigated that much. The existing literature indicates that student teachers learn from observing their professors teach. However, that knowledge is mostly acquired indirectly and passively because student teachers are neither encouraged nor challenged to reflect on teaching strategies and teaching methodologies utilized by teacher educators. As this study revealed, apprenticeship of observation can be turned into an active way of learning pedagogical knowledge and teaching skills.

\section{Acknowledgments}

We are very grateful to our research participants for participating in our study. 


\section{REFERENCES}

[1] British Council. The impact of English, what it's worth to the UK and what it matters to the world, Retrieved from https://www.britishcouncil.org/sites/default/files/english-ef fect-report-v2.pdf, 2017.

[2] F. G. Fang. World Englishes or English as a lingua franca: Where does English in China stand? An ideological negotiation and attitudinal debate of the use and function of English in the Chinese context, English Today, Vol.33, No.1, 19-24, 2017.

[3] A. M. Dávila. Construction of EFL teacher educators' knowledge base in a teacher education program in Nicaragua (Order No. 10830853), Available from Dissertations \& Theses @ Southern Illinois University at Carbondale; ProQuest Dissertations \& Theses A\&I. (2190678760), Retrieved from https://search-proquest-com .proxy.lib.siu.edu/docview/2190678760?accountid=13864, 2018.

[4] A. M. Dávila, J. E. V. Espinoza. Knowledge and skills used by Nicaraguan English teachers in the EFL classroom, International Journal of Current Research, Vol.11, No.1, 330-333, 2019.

[5] R. Day. Models and the knowledge base of second language teacher education, University of Hawaii's Working Papers in ESL, Vol.11, No.2, 1-13. 1993.

[6] F. Faez. Points of departure: Developing the knowledge base of ESL and FSL teachers for K-12 programs in Canada, The Canadian Journal of Applied Linguistics, Vol.14, No.1, 29-49, 2011.

[7] R. C. Lafayette. Subject matter content: what every foreign language teacher needs to know, In G. Gunterman (Ed.), Developing language teachers for a changing world (pp. 124-158). Chicago: National Textbook Company, 1993.

[8] D. F. Macías. An exploration of EFL teachers' awareness of the sources of pedagogical knowledge in a teacher Education program, Profile Issues in Teachers Professional Development, Vol.15, No.2, 99-114, 2013.

[9] S. Moradkhani, R. Akbari, R. Ghafar Samar, G. R. Kiany. English language teacher educators' pedagogical knowledge base: The macro and micro categories, Australian Journal of Teacher Education, Vol.38, No.10, 123-141, 2013.

[10] J. C. Richards. Beyond training, New York: Cambridge University Press, 1998.

[11] J. C. Richards. Curriculum approaches in language teaching: Forward, central, and backward design, RELC Journal, Vol.44, No.1, 5-33, 2013.

[12] A. V. Kelly. The curriculum theory and practice, Thousand Oaks, California: SAGE Publications, 2009.

[13] A. C. Orstein, F. P. Hunkins. Curriculum: Foundations, principles, and issues, Vivar, Malaysia: Pearson Education, 2018.

[14] S. M. Schiro. Curriculum theory: Conflicting visions and enduring concerns, Thousand Oaks, California: SAGE Publications, 2013.

[15] R. W. Tyler. Basic principles of curriculum and instruction, Chicago, Illinois: The University of Chicago Press, 1949.

[16] G. Wiggins, J. McTighe. Understanding by design, Alexandria, Virginia: Association for Supervision and Curriculum Development, 2005.

[17] L. Shulman. Knowledge and teaching: Foundations of the new reform, Harvard Educational Review, Vol.57, No.1, $1-23,1987$.

[18] D. Freeman, K. E. Johnson. Reconceptualizing the knowledge-base of language teacher education, TESOL Quarterly, Vol.32, No.3, 397-417, 1998.

[19] S. Arıŏul. Understanding foreign language teachers' practical knowledge: What's the role of prior language learning experience? Journal of Language and Linguistic Studies, Vol.3, No.1, 169-181, 2007.

[20] W. Zhang. In search of English as a foreign language (EFL) teachers' knowledge of vocabulary instruction (Doctoral Dissertation), Retrieved from Google Scholar:http://schola rworks.gsu.edu/cgi/viewcontent.cgi?article $=1000 \&$ context =alesl_diss, 2008 .

[21] B. McLaughlin, R. Heredia. Information-processing approaches to research on second language acquisition and use, Handbook of second language acquisition, 213-228, 1996.

[22] S. L. McGregor, J. A. Murnane. Paradigm, methodology and method: Intellectual integrity in consumer scholarship, International journal of consumer studies, Vol.34, No.4, 419-427, 2010.

[23] E. Husserl. 1859-1938 Cartesian meditation: An introduction to phenomenology, The Hague, the Netherlands: Martinus Nijhoff, 1960.

[24] C. Moustakas. Phenomenological research methods, Thousand Oaks, CA: Sage, 1994.

[25] M. Van Manen. Researching lived experience: Human science for an action sensitive pedagogy, Albany: State University of New York Press, 1990.

[26] J. W. Creswell. Qualitative inquiry: Choosing among five traditions, Thousand Oaks, CA: Sage, 1998.

[27] R. H. Hycner. Some guidelines for the phenomenological analysis of interview data, Human studies, Vol.8, No.3, 279-303, 1985.

[28] J. W. Creswell. Research design: Qualitative, quantitative, and mixed method approaches, Thousand Oaks, CA: SAGE Publications, 2014.

[29] J. W. Creswell. Qualitative inquiry and research design: Choosing among five approaches, Thousand Oaks, CA: SAGE Publications, 2013.

[30] J. C. Welman, S. J. Kruger. Research methodology for the business and administrative sciences, Johannesburg, South Africa: International Thompson, 1999.

[31] M. Lichtman. Qualitative research in education, California: SAGE Publications, 2013. 
[32] M. B. Miles, A. M. Huberman, J. Saldana. Qualitative data analysis: A methods sourcebook, Thousand Oaks, CA: Sage, 2014.

[33] Y. S. Lincoln, E. G. Guba. Naturalistic inquiry, Newbury Park, CA: Sage, 1985.

[34] S. B. Thomson. Qualitative research: validity, Joaag, Vol.6, No.1, 77-82, 2011.

[35] D. G. Cope. Methods and meanings: credibility and trustworthiness of qualitative research, In Oncology nursing forum, Vol.41, No.1, 89-91, 2014.

[36] J. W. Creswell, D. L. Miller. Determining validity in qualitative inquiry, Theory into practice, Vol.39, No.3, 124-130, 2000.

[37] N. K. Denzin. The research act: A theoretical orientation to sociological methods, New York: McGraw-Hill, 1978.

[38] D. F. Polit, C. T. Beck. Nursing research: Generating and assessing evidence for nursing practice, Philadelphia, PA: Lippincott Williams and Wilkins, 2012.

[39] R. E. Mayer. Applying the science of learning, Boston: Pearson/Allyn \& Bacon, 2011.

[40] R. Metchell, F. Myles. Second language learning theories, Great Britain: Hodder Education, 2004.

[41] N. Brooks. Language and Language Learning, New York: Harcourt, 1960.

[42] R. Lado. Linguistics across cultures: Applied linguistics for language teachers, Michigan: University of Michigan Press ELT, 1957.

[43] J. P. Lantolf. Sociocultural theory and second language learning: Introduction to the special issue, The Modern Language Journal, Vol.78, No.4, 418-420, 1994.

[44] J. P. Lantolf, G. Appel. Vygotskian approaches to second language research, Norwood, NJ: Ablex Publishing Corporation, 1994.

[45] L. S. Vygotsky. The collected works of L. S. Vygotsky: Volume 1, Thinking and speaking, New York, NY: Plenum Press, 1987.

[46] S. D. Krashen. Principles and practice in second language acquisition, Oxford: Pergamon, 1982.

[47] J. C. Richards. Teaching Listening and Speaking: From theory to Practice, Singapore: Regional Language Center, 2009.

[48] S. Borg. Teacher cognition in language teaching: A review of research on what language teachers think, know, believe, and do, Language Teaching, Vol.36, No.2, 81-109, 2003.

[49] P. Grossman. The making of a teacher: Teacher knowledge and teacher education, New York: Teachers' College, 1990.

[50] D. Lortie. Schoolteacher: A sociological study, Chicago: University of Chicago Press, 1975.

[51] M. Amin Mekheimer, H. Shabieb Aldosari. Evaluating an Integrated EFL Teaching Methodology in Saudi Universities: A Longitudinal Study, Journal of Language Teaching \& Research, Vol.4, No.6, 2013.
[52] I. S. P. Nation. Teaching EFL/ESL reading and writing, New York: Routledge, 2009.

[53] S. S. P. Nation, J. Newton. Teaching ESL/EFL listening and speaking, New York and London: Routledge Taylor and Francis Group, 2009.

[54] R. Oxford. Integrated Skills in the ESL/EFL Classroom, ERIC Digest, 2001.

[55] S. Yimwilai. An Integrated Approach to Teaching Literature in an EFL Classroom, English Language Teaching, Vol.8, No.2, 14-21, 2015.

[56] S. M. Schiro. Curriculum theory: Conflicting visions and enduring concerns, Thousand Oaks, California: SAGE Publications, 2013.

[57] J. Crandall. Language teacher education, Annual Review of Applied Linguistics, Vol.20, 34-58, Cambridge: Cambridge University Press, 2000.

[58] R. Day. Models and the knowledge base of second language teacher education, University of Hawaii's Working Papers in ESL, Vol.11, No.2, 1-13, 1993.

[59] A. Bandura. Vicarious processes: A case of no-trial learning, In Advances in experimental social psychology, Vol.2, 1-55, Academic Press, 1965.

[60] T. Mayes, F. Dineen, J. McKendree, J. Lee. Learning from watching others learn, In Networked learning: perspectives and issues, 213-227, Springer, London, 2002.

[61] P. M. Lightbown, N. Spada, How languages are learned, Oxford: Oxford University Press, 2006.

[62] R. Jack. Teaching listening and speaking from theory to practice, Cambridge University, Printed in The United States of America, 2008.

[63] J. Anderson. Cognitive psychology and its implications, New York, NY: Freeman, 1985.

[64] J. P. Powell. Autobiographical learning, In Boud, et al. (pp. 41-51), 1985

[65] J. Pak. Find out how you teach, Adelaide, Australia: National Curriculum Resource Centre, 1985.

[66] J. C. Richards. Towards reflective teaching, English Teachers Journal-Israel, 59-63, 1995.

[67] A. Bandura. Self-efficacy, the Corsini encyclopedia of psychology, 1-3, 2010.

[68] A. Bandura, W. H. Freeman, R. Lightsey. Self-efficacy: The exercise of control, 1999.

[69] D. H. Schunk. Self-efficacy and academic motivation, Educational psychologist, Vol.26, No.3-4, 207-231, 1991. 